\title{
SURFACE TREATMENTS BY LASER TECHNOLOGY
}

\author{
M. A. Montealegre, " G. Castro, P. Rey, J. L. Arias, P. Vázquez, M. González \\ AIMEN Technology Centre, Relva 27 A, Torneiros, 36410 Porriño, \\ Pontevedra, Spain
}

\begin{abstract}
Industrial applications require parts of components with specific surface properties such are good corrosion resistance, wear resistance and hardness. Alloys with those properties are usually very expensive and there is a great interest in reducing the cost of components for fulfilling these requirements. In this sense, laser surface processing has been used as a cost-effective technique to improve the surface properties of materials, by use of the laser beam heat for modification of its structure and physical characteristics. Laser surface treatments can be divided into direct processes, which only need the generated heat, such are hardening and melting, and processes which need filler material as alloying and cladding. Therefore, the aim of this paper is to summarize the results of several works based on laser surface treatments, in particular, hardening and melting of hot and cold work steels, and laser cladding of forming tools with nanoparticles. The microstructural characterization and mechanical properties (microhardness, wear resistance) will be described in each case.
\end{abstract}

Keywords: Laser, cladding, hardening, nanoparticles, Nd:YAG laser, diode laser.

\section{INTRODUCTION}

There is a need in different industry sectors to improve the performance of material surface under wear and corrosion environments, which cannot be fulfilled by the conventional surface modifications and coatings.

One example is tool steels, which are commonly used for manufacturing moulds, dies and other components that are subjected to extremely high load in almost all industry sectors. These tools steels require high wear and corrosion resistance, either for cold work or hot work applications.

Another different case is the ultra high strength steels used in automotive industry for bodyin-white applications [1]. They allow increasing the car passenger safety, while reducing the vehicle weight and, subsequently, resulting in a fuel consumption and $\mathrm{CO}_{2}$ emission reduction. Nevertheless, they sometime present a formability problem, which could be solved by local softening or hardening of some parts of the formed steel sheet.

One way to improve the surface properties of materials is the laser surface engineering [2, 3]. Laser surface engineering encompasses several applications that are mainly related to enhancing one of the surface dependent properties, like hardness, friction, fatigue and resistance to wear, corrosion, etc. The steady development of high power lasers and their suitability to be introduced in production lines has encouraged the industrial application of laser surface treatments.

The methods of laser surface treatment of materials have been classified in to two types [2,3]:

- Thermal process: with no change of surface composition (no material addition), like laser cutting, welding, tempering, annealing, melting, and transformation hardening.

- Thermo-chemical process: with change in composition of surface (material addition), like laser cladding, alloying, where the process differ in the metallurgical structure.

Furthermore, the advantages of these surface treatments include flexibility and the possibility of treating small areas, leaving the others parts unaffected $[2,3]$.

Laser surface hardening is a promising process for enhancing the surface properties of a component. It has been shown to improve tribological properties of the metal alloys and ceramics [4-9], or their corrosion behaviour $[10,11]$. Under laser irradiation, the surface temperature is increased above the steel austinizing temperature and, by heat conduction to the bulk material, a thin steel layer is fast cooled down by a self-quenching process. The research on laser surface hardening includes the use of 
different high power lasers: $\mathrm{CO}_{2}, \mathrm{Nd}$ :YAG or diode lasers.

Another way to improve the surface properties of the material is laser surface melting. Laser surface melting produces an increase of the hardness, toughness and wear resistance of the material surface in a very short time [12-14]. This process has been investigated by different authors by use of high power lasers. $\mathrm{CO}_{2}$ or $\mathrm{Nd}$ :YAG lasers have been the most used [12-14]. The rapid melting of the surface layer induced by irradiating with a laser beam, and its rapid solidification in contact with the cold substrate, are the main characteristics of this treatment. At the melted surface, this process produces a high homogenous and very fine dendritic microstructure, without the large typical carbides of tool steels [14].

The surface properties can also be improved by deposit a protective layer. Laser cladding process can produce a $0.3-1 \mathrm{~mm}$ thick coating onto a work piece, joining both materials by a fusion bond $[2,3]$. A clad track is obtained by injecting powder particles into the molten pool produced by a moving laser beam. In order to cover the areas considerably larger than the diameter of the laser beam, successive partially overlapping tracks are deposited. The powder injected can be either the same material as the work piece, or powder which could improve the surface properties. When the powder material presents poor flow behaviour, it is pre-placed on the component surface. This is the case of nanoparticles addition to the powders in order to obtain a nanocomposite or nano-reinforced coating [16-18].

In the present paper, we provide an overview of the application of lasers for surface engineering, hardening, melting, and cladding.

\section{EXPERIMENTAL PROCEDURE}

\subsection{Laser surface hardening}

Laser hardening treatment was performed in two different steels, a dual phase steel (DP 600) and a hot work tool steel, AISI H13 (DIN 1.3344).

DP steels are dual phase, ultra high strength cold forming steels with a microstructure that contains ferrite, which is a soft phase, and contributes to good formability, and martensite, which is a hard phase, and contributes to the strength of the material. These steels are established according to their lowest tensile strength. The selected DP steel for this study was a DP $6001 \mathrm{~mm}$ thick sheet with $11 \times 7 \mathrm{~mm}$ dimensions. Its chemical composition is provided in Table 1.
The H13 hot-work tool steel specimens of $130 \times 210 \times 20 \mathrm{~mm}$ were quenched and tempered to Rockwell hardness of 49 HRC (about $500 \mathrm{HV}$ ). Its chemical composition is given in the 0 .

Table 1. Chemical composition of DP600 (wt\%).

\begin{tabular}{|c|c|c|c|c|c|c|}
\hline $\mathrm{C}$ & $\mathrm{Si}$ & $\mathrm{Mn}$ & $\mathrm{P}$ & $\mathrm{S}$ & $\mathrm{Nb}$ & $\mathrm{Al}$ \\
\hline 0.11 & 0.40 & 0.90 & 0.015 & 0.006 & - & 0.04 \\
\hline
\end{tabular}

Table 2. Chemical Composition of H13 (wt\%).

\begin{tabular}{|c|c|c|c|c|c|c|c|c|}
\hline $\mathrm{C}$ & $\mathrm{Si}$ & $\mathrm{Mn}$ & $\mathrm{P}$ & $\mathrm{S}$ & $\mathrm{Ni}$ & $\mathrm{Cr}$ & $\mathrm{Mo}$ & $\mathrm{V}$ \\
\hline 0.40 & 0.80 & 0.40 & 0.009 & 0.004 & 0.16 & 4.50 & 1.13 & 0.71 \\
\hline
\end{tabular}

Experiments were performed by using two different lasers, a direct high power diode laser and diode pumped Nd:YAG one.

The $3.3 \mathrm{~kW}$ direct diode laser (Laserline, model LDL 160-3300) was mounted on a 6 axes robot system (ABB, model IRB4400). The square shape of the delivering beam was focused to the $15 \times 15 \mathrm{~mm}^{2}$ size spot on the work piece

The Nd:YAG-laser was a Rofin DY044, with $4.4 \mathrm{~kW}$ maximum power. The laser beam was guided by a fiber optic to the focusing optics, moved by an IRB6600 ABB robot. The unfocused laser beam on the material surface was $4 \mathrm{~mm}$ in diameter, being moved over the surface to obtain $4 \mathrm{~mm}$ wide tracks. In order to treat wider zones, different tracks were overlapped with an overlapping percentage of $25 \%$.

The process temperature was controlled using a LASCOM system, acting on the power from the diode laser to maintain the temperature set value. 0 shows the process graph, where the temperature curve is kept constant while there are little changes in the power curve.

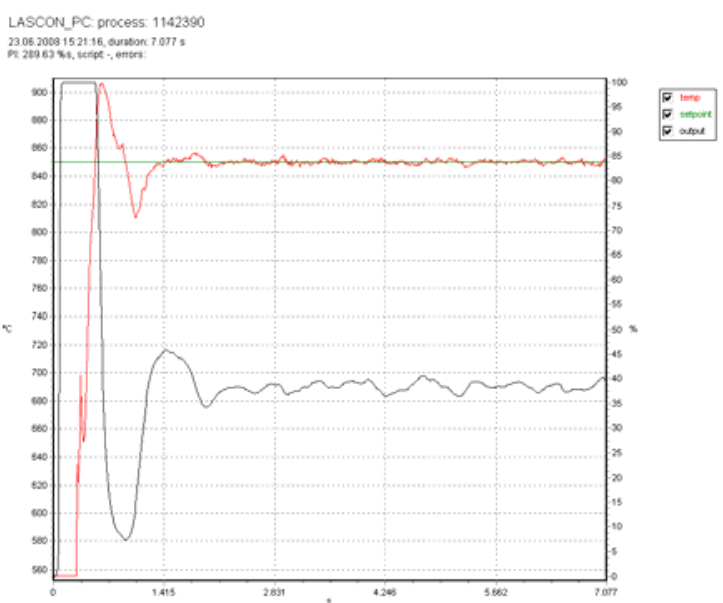

Figure 1. Temperature and laser power graph. 


\subsection{Laser surface melting}

Specimens of high speed steel AISI M2 (DIN 1.3343 ), the steel widely used in tooling industry, were subjected to a standard heat treatment for this type of steel (quenched and three tempered) to achieve the Rockwell hardness of $60 \mathrm{HRc}$. Its chemical composition is shown in the Table 3 .

Table 3. Chemical Composition of H13 (wt\%).

\begin{tabular}{|c|c|c|c|c|c|}
\hline $\mathrm{C}$ & $\mathrm{Si}$ & $\mathrm{Cr}$ & $\mathrm{W}$ & $\mathrm{Mo}$ & $\mathrm{V}$ \\
\hline 0.85 & 0.25 & 4.15 & 6.30 & 5.00 & 1.85 \\
\hline
\end{tabular}

Surface melting was performed with the diode pumped Nd: YAG, which ensures the melting of an adequate thickness of material due to its Gaussian beam power profile. The parameters used in the laser melting are shown in 0 . Four treatments were performed at the same power, by varying the processing speed and the beam diameter. As a result, the energies per unit area provided by the laser beam were 23.66, 13.33, 11.11 and $5.55 \mathrm{~J} / \mathrm{mm}^{2}$ for the $\mathrm{M} 21$, M22, M23 and M24 laser tracks, respectively.

Table 4. Nd:YAG laser parameters

\begin{tabular}{|c|c|c|c|}
\hline $\begin{array}{c}\text { Laser } \\
\text { treatment }\end{array}$ & $\begin{array}{c}\text { Laser } \\
\text { Power } \\
(\mathrm{kW})\end{array}$ & $\begin{array}{c}\text { Beam } \\
\text { scanning } \\
\text { speed, mm/s }\end{array}$ & $\begin{array}{c}\text { Beam } \\
\text { diameter, } \\
\text { mm }\end{array}$ \\
\hline M21 & 2 & 25 & 3 \\
\hline M22 & 2 & 25 & 6 \\
\hline M23 & 2 & 60 & 3 \\
\hline M24 & 2 & 60 & 6 \\
\hline
\end{tabular}

\subsection{Laser cladding}

Specimens of structural steel S235, the low alloyed steel, were used as substrate. A mixture of Co alloy (Stellite 6, 45-90 $\mu \mathrm{m}$ ) and $0.5 \%$ ceramic nanopowders $\left(\mathrm{Y}_{2} \mathrm{O}_{3}, 30-50 \mathrm{~nm}\right.$;) was used as the coating material to improve. Mixing was performed in a rotary ball mill Simoloyer CM01 (Zoz) to achieve an intimate mixture between the alloy and the ceramic. Mixtures were carried out for $1200 \mathrm{~s}$ at 900 RPM.

Experiments were performed by using a direct diode laser. The square shape of the delivered beam was focused to a $3 \times 3 \mathrm{~mm}^{2}$ size spot on the work piece. The blended powder mixtures of Stellite 6 and ceramic nanoparticles were placed in the powder feeder from Medicoat. The powder was transported by an argon stream to the powder coaxial nozzle COAX 8 (Fraunhofer IWS), and blown on the substrate at the same laser beam incidence point.

The coating samples were produced by using the powder feed rate between $6-12 \mathrm{~g} / \mathrm{min}$, the traverse speed between $8-10 \mathrm{~mm} / \mathrm{min}$, the protection argon flow of $10-13 \mathrm{1} / \mathrm{min}$ and the laser power of $1.1-1.4 \mathrm{~kW}$.

\subsection{Microstructural and Mechanical Characterization}

Microstructural characterization was performed by the conventional metallographic techniques. A HITACHI FE-4500 Field Emission Scanning Electron Microscope (FEGSEM) coupled with an energy dispersive X-ray spectroscopy (EDS) microprobe and a OLYMPUS metallographic optical microscope (OM) were used. The composition of the different observed phases was analyzed by an energy dispersive spectrometer (EDS) attached to the SEM. The samples were polished to a near mirror finish, by using abrasive papers followed by a final diamond polishing. Afterwards, they were etched with either vilella or nital solution in order to reveal the microstructure under the OM.

Mechanical behaviour of the new surfaces was assessed in terms of microhardness and wear properties. Microhardness measurements were performed on the polished cross section of the samples by using a EMCOTEST M1C 010 automatic digital microhardness tester, by using a Vickers indenter under the test load of $50 \mathrm{kgf}$ and 15 -seconds dwell time.

Tribological tests were performed in a high temperature pin-on-disk tribometer by Microtest $2 / 60 / \mathrm{SCM}$. Test conditions are indicated in the 0 . All tests were repeated three times under the same conditions.

Table 5. Friction-wear test conditions

\begin{tabular}{|c|}
\hline Wear track diameter $(\mathrm{mm}): 8$ \\
\hline Pin $4 \mathrm{~mm}$ diameter alumina ball \\
\hline Normal load $(\mathrm{N}): 10$ \\
\hline Sliding speed $300 \mathrm{rpm}$ (rotate) $0.25 \mathrm{~ms}^{-1}$ (linear) \\
\hline Sliding distance $(\mathrm{m}) 450$ \\
\hline Test temperature $\left({ }^{\circ} \mathrm{C}\right) 250^{\circ} \mathrm{C}$ \\
\hline
\end{tabular}

The specific wear rate coefficients, K-values, were calculated using the Archard equation [19].

\section{RESULTS AND DISCUSSION}

\subsection{Laser hardening}

Figure 2 shows a photograph of the DP600 surface with different laser tracks. They were produced at a $10 \mathrm{~mm} / \mathrm{s}$ of processing speed and a surface temperature of $850^{\circ} \mathrm{C}$. 


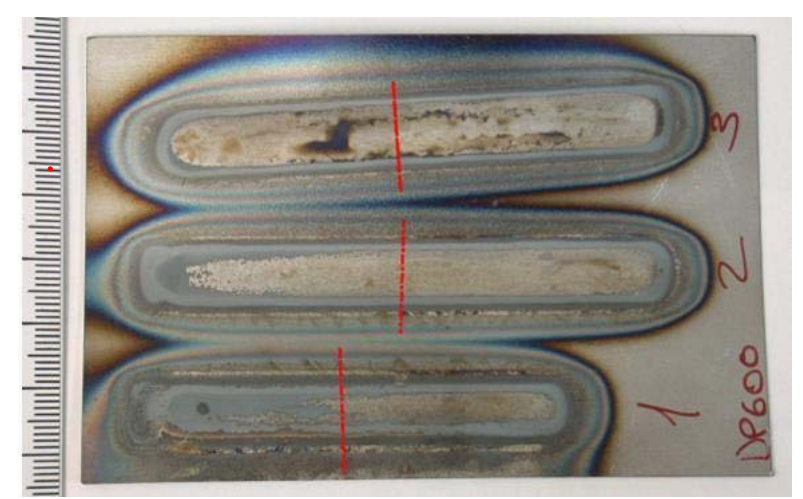

Figure 2. DP 600 steel plate of $1 \mathrm{~mm}$ thickness with several laser tracks.

Figure 3 shows a macrograph of the cross section of one of the treated areas. The laser-treated area can be seen in the darker shade and, in the lighter tones, the area that corresponds to the heataffected zone. As shown, the complete thickness of the sheet has been affected by the treatment. The width of treated area practically matches that of the beam spot $(15 \mathrm{x} 15 \mathrm{~mm}), 4 \mathrm{~mm}$ of which approximately correspond to the transition zone and the other to the hardened one.

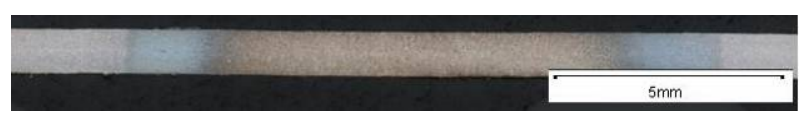

Figure 3. Optical macrographt showing the cross section of one laser track.
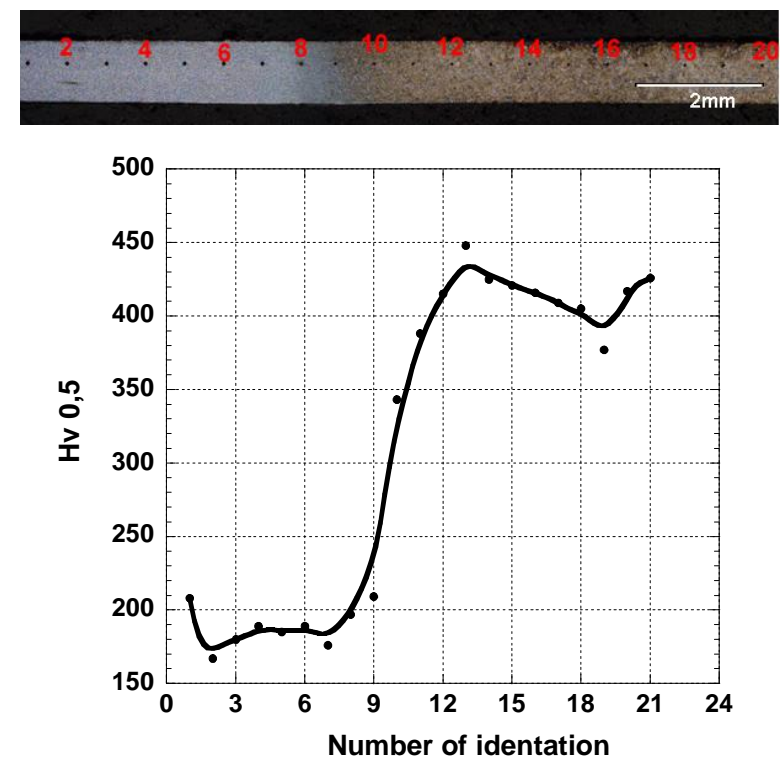

Figure 4. Macrograph and hardness curve.

Hardness was evaluated parallel to the surface from the treated area to the base material, through the transition and heat affected zones. Figure 4 is showing the graph with the hardness values obtained in a cross section along the laser-treated zone. The hardness values increases over $100 \%$ relative to the non-laser hardened material.

The hardness of the laser-treated part of the sheet changes depending on the laser beam traveling speed. When the speed is low, the heat input is high at each point; and the surface temperature is high enough to reach the austenizing region, and even to increase the austenite grain size.

The details of the observed microstructures are shown in the next figures, where it is possible to observe the microstructure evolution from the received material to the laser-heated zone. Figure 5 shows the micrograph of as received condition, a typical ferritic matrix with some amount of martensite, typical of these DP steels. Transition zone experiments show an increase of the hardness values, from $180 \mathrm{Hv}$ in the as received condition to $340-380 \mathrm{HV}$ in the laser-hardening zone. Microstructure of this zone (Figure 6) shows an increase of the martensite structure inside of the ferrite matrix. Figure 7 shows the central zone of the laser track. This zone reveals a complete austenization transformation resulting in a martensite microstructure in this area. Hardness values are higher than $400 \mathrm{Hv}$ in this hardened region. It should be pointed out that austenite and martensite cannot be clearly distinguished from each other in the micrograph.

The main conclusions that can be drawn from this study on laser heat treatment of DP600 steel are:

- From the test, it is possible to confirm that this material is susceptible to the laser hardening treatment. It is possible to harden the complete thickness of the sample. The hardened width matches the laser beam dimensions.

- After the laser heat treatment, the hardness increases more than $100 \%$, relative to the material in as received condition.

Tool steel 13 specimens were treated with two different sets of parameters, identified by $\mathrm{T} 1$ and $\mathrm{T} 2$ in Table 6. The heat input is approximately the same for both set of parameters, $3.5 \mathrm{~kJ} / \mathrm{cm}^{2}$. 


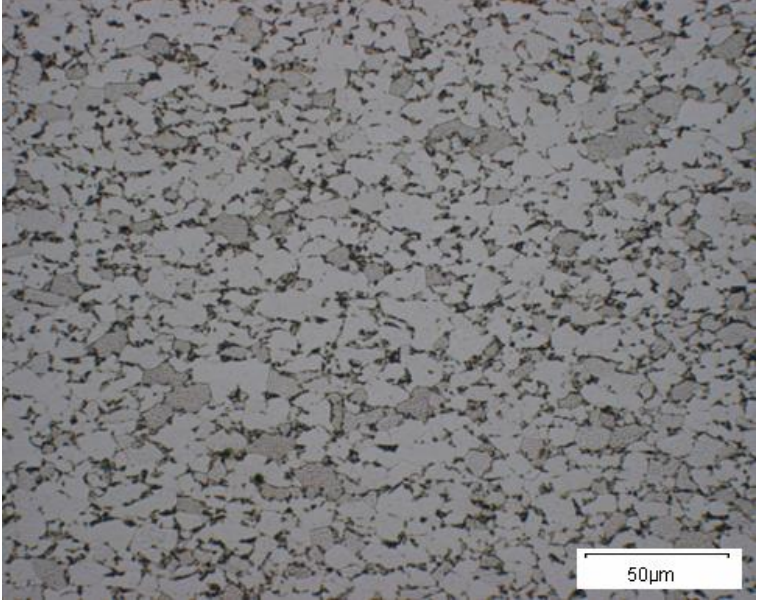

Figure 5. Microstructure in as received condition of DP600.

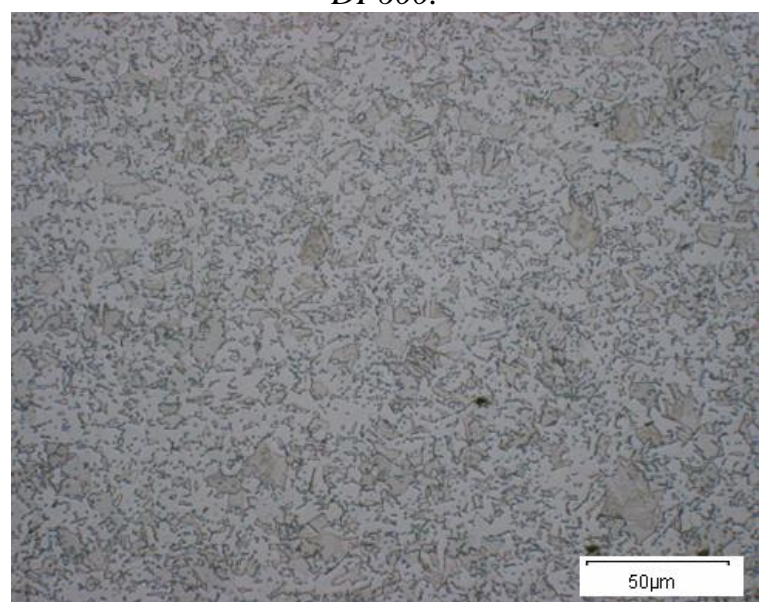

Figure 6. Fig. Microstructure in transition zone between as received condition and laser treated zone.

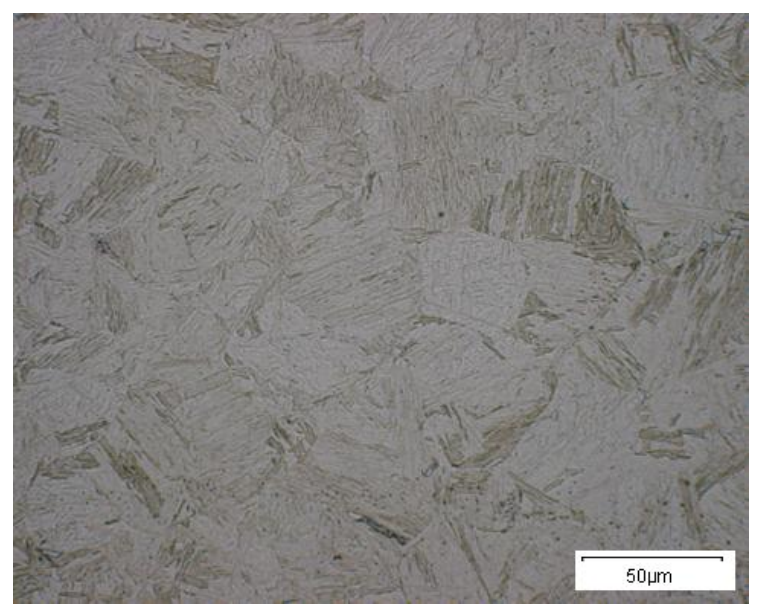

Figure 7. Microstructure of laser treated zone.

Table 6. H13 tool steel processing parameters.

\begin{tabular}{|c|c|c|}
\hline Track & $\mathrm{P}_{\mathrm{L}}(\mathrm{kW})$ & $\mathrm{v}(\mathrm{mm} / \mathrm{s})$ \\
\hline $\mathrm{T} 1$ & 1.4 & 30 \\
\hline $\mathrm{T} 2$ & 3.5 & 85 \\
\hline
\end{tabular}

Figure 8 and 9 show the microstructure of the laser track cross sections for $\mathrm{T} 1$ and $\mathrm{T} 2$ conditions. The treated area depth is around $400 \mu \mathrm{m}$ for $\mathrm{T} 1$ and
$350 \mu \mathrm{m}$ for $\mathrm{T} 2$. In $\mathrm{T} 2$ there is a re-melted layer in the outermost region, with a fine grain martensitic microstructure, formed by the dendritic structure growth. In both of the treatment conditions, there is a smooth dark transition zone between the treated zone and base material.

Values of microhardness Vickers were measured in the cross sections at different depths: near surface, in the middle of the treated zone, and in the dark transition to the base material. For the specimens with laser treatment T1, the Vickers hardness measurements in each zone give values of 802, 766 and $777 \mathrm{HV}$, respectively. Compared to the base metal, with $500 \mathrm{HV}$, all the treated layer has increased its hardness for over $50 \%$. Concerning the specimens with laser treatment $\mathrm{T} 2$, the hardness values were 770,760 and $690 \mathrm{HV}$, respectively.

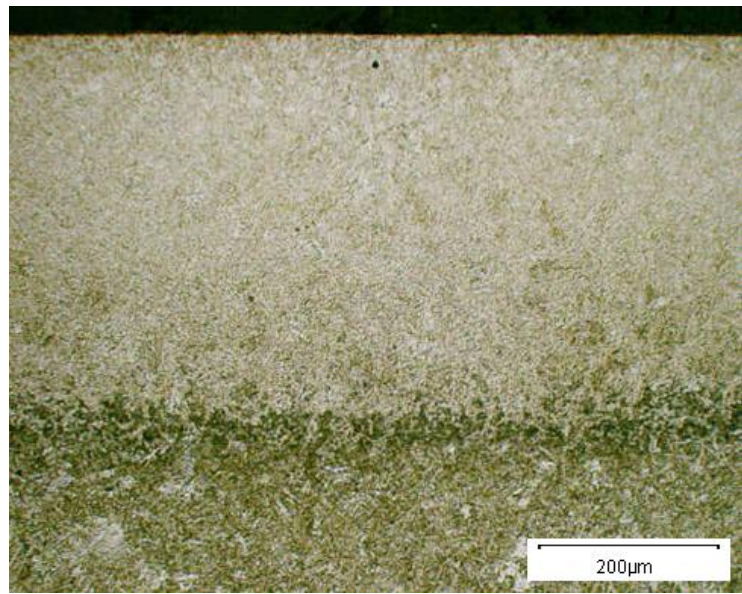

Figure 8. Optical micrograph showing cross section of single track with laser treatment $\mathrm{T} 1$.

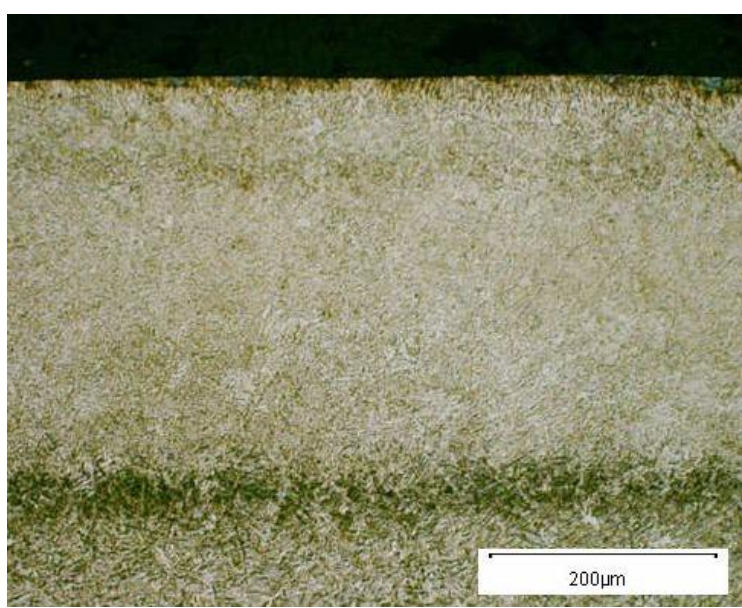

Figure 9. Optical micrograph showing cross sections of single track with laser treatment $T 2$.

When a wide region of the component is to be treated by laser, different adjacent tracks have to be performed. In order to obtain a layer with the same thickness over the whole laser-treated region, a $25 \%$ 
overlapping between adjacent tracks has to be carried out (Figure 10).

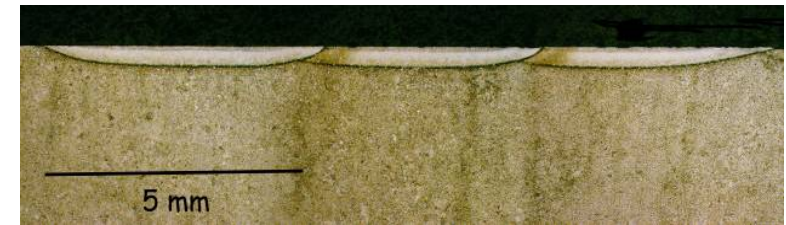

Figure 10. Optical micrograph showing overlapped laser tracks in $T 2$ conditions.

In the overlapping region, there is a decrease in hardness down to $650 \mathrm{HV}$ for $\mathrm{T} 1$ and $700 \mathrm{HV}$ for T2 (Figure 10), where the microstructure is still martensitic, although it has been heat-affected (tempering).
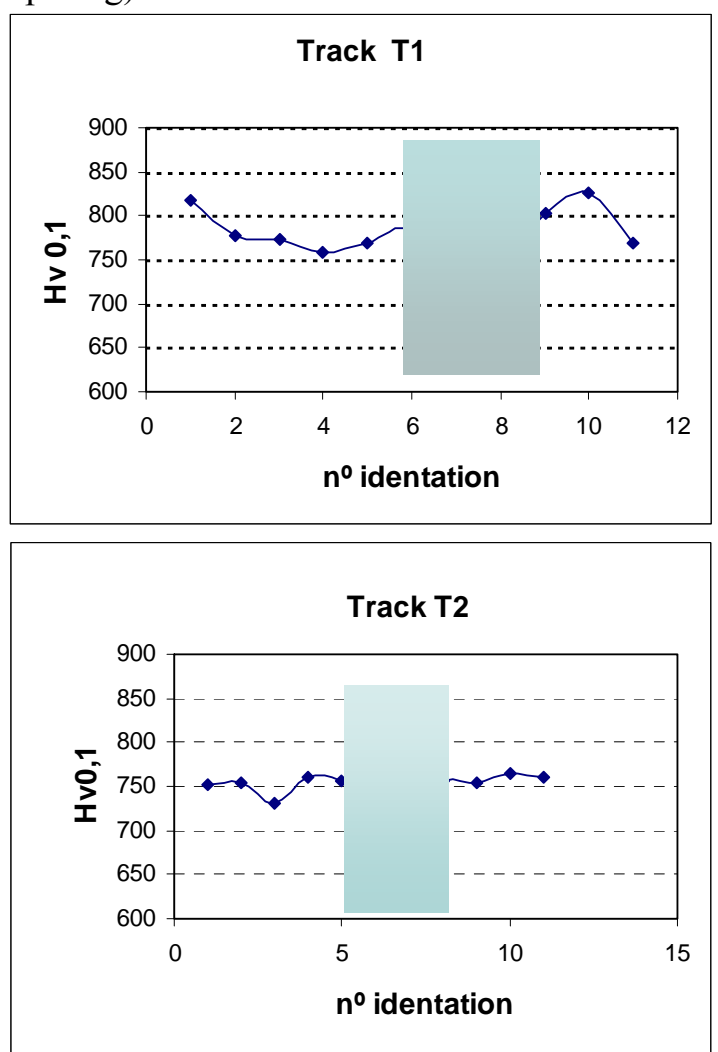

Figure 11. Variations of hardness values in overlapped laser tracks. Shaded zone corresponds to overlapping.

Table 7. Depth of wear tracks, wear volume and specific wear ratio.

\begin{tabular}{|c|c|c|c|}
\hline & Depth $(\mu \mathrm{m})$ & $\begin{array}{c}\text { Volume } \\
\left(\mathrm{mm}^{3}\right)\end{array}$ & $\mathrm{K}\left(\mathrm{mm}^{3} / \mathrm{N} . \mathrm{m}\right)$ \\
\hline Base & 23 & 0.27 & $5.9 \times 10^{-5}$ \\
\hline T1 & 30 & 0.39 & $8.7 \times 10^{-5}$ \\
\hline T2 & 20 & 0.2 & $4.5 \times 10^{-5}$ \\
\hline
\end{tabular}

The values of the dimensional measurements of the depth of wear tracks, wear volume and specific wear ratio for both $\mathrm{T} 1$ and $\mathrm{T} 2$ laser treatment conditions are shown in Table 7 . For the laser treatment $\mathrm{T} 1$, the wear depth is higher than for the base metal, as well as the friction coefficient and the total wear volume. On the contrary, the laser treatment T2 presents a higher wear resistance. The friction coefficient is also the lowest for T2 (Figure 12), which can promote sliding and, therefore, the wear sliding resistance. The friction coefficient is also almost constant during entire sliding distance, while for $\mathrm{T} 1$ conditions it continuously increases. This fact could denote an abrasive mechanism due to wear debris.

Concluding, laser treatment T1 presents poorer wear behaviour than base material, while conditions $\mathrm{T} 2$ shows a better behaviour. This fact could be explained by the different microstructure of both surfaces (Figure 13). Treatment T2 gives place to a $20 \mu \mathrm{m}$ deep fine dentritic structure, followed by a 15 $\mu \mathrm{m}$ thick coarse dentritic one. Whithin this dentrites the martensite grains are much finer than in the microstructure shown by the T1 laser track. Moreover, the interdendritic space is filled by a carbide $(\mathrm{Cr}, \mathrm{V}$, Mo) enriched microstructure.

The main conclusion derived from this study is that it has been found that the most appropriate laser treatment should be the one with a $3500 \mathrm{~W}$ laser power and $8 \mathrm{~mm} / \mathrm{s}$ processing velocity. It has given place to an improvement in wear behaviour of the material surface, due to the formation of a thin fine dendritic structure, with an increasing concentration of $\mathrm{Cr}, \mathrm{V}$ and Mo carbides at the interdendritic space.

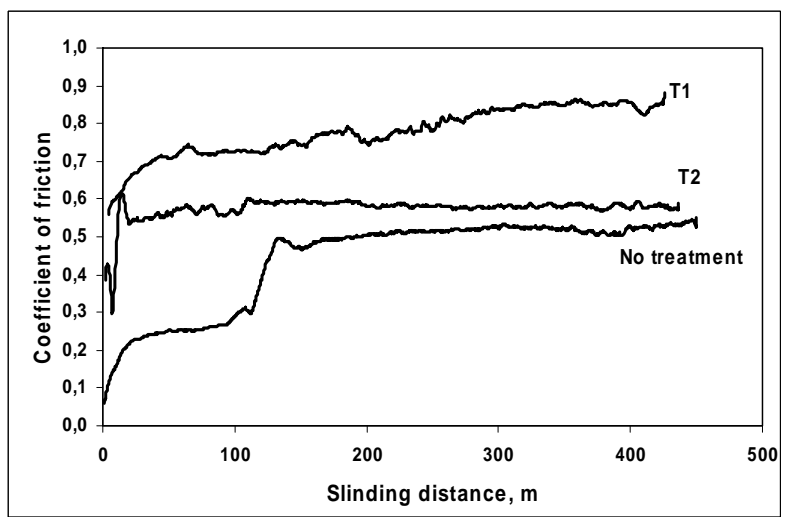

Figure 12. Friction coefficients vs. sliding distance during pin on disc tests for each laser treatment To conclude, the laser treatment $T 1$ presents poorer wear behaviour than the base material, while conditions $T 2$ shows a better behaviour. This fact could be explained by the different microstructure of both surfaces (Figure 13). Treatment T2 gives place to a $20 \mu \mathrm{m}$ deep fine dentritic structure, followed by a $15 \mu \mathrm{m}$ thick coarse dentritic one. Within these dentrites the martensite grains are much finer than

in the microstructure shown by the T1 laser track. Moreover, the interdendritic space is filled by a carbide (Cr, V, Mo) enriched microstructure. 


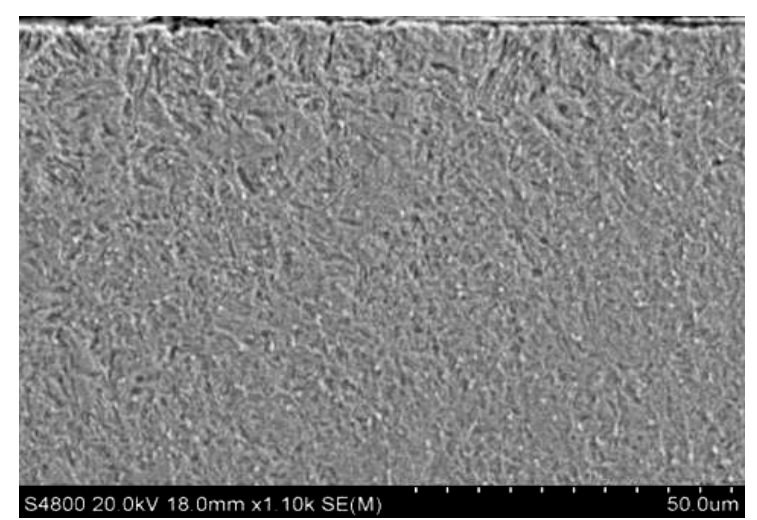

Figure 13. SEM micrographs showing microstructure near surface for laser treatment T1.

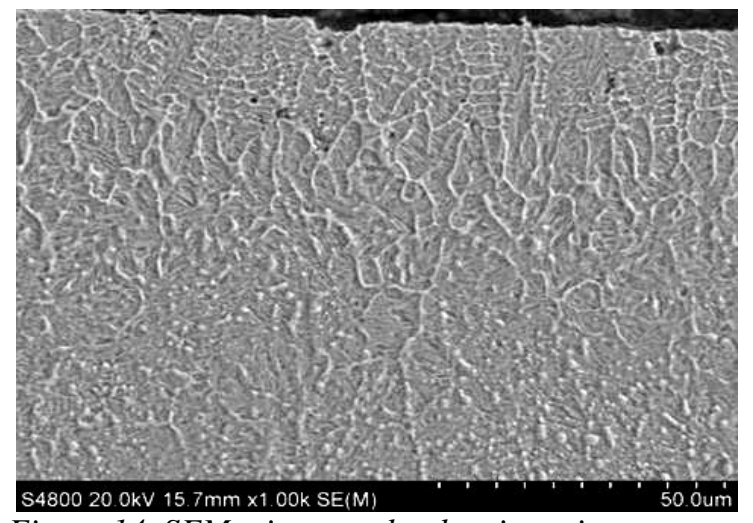

Figure 14. SEM micrographs showing microstructure near the surface for laser $T 2$.

\subsection{Laser surface melting}

Laser melting produces microstructural changes on the steel surface. The optical micrograph presented in the 0 , shows a cross section (M21) of the laser melted surface layer. From the top of the surface, four different zones are observed: the laser melted zone (LMZ) where complete melting occurred, the partial melted zone (PMZ) where the materials were partially molten, the heat- affected zone (HAZ) where the temperature was not high enough for melting, and the unaffected base material (BM). The treatment temperature and the cooling rate are responsible for the microstructural differences.

Figure 16 shows the microstructure of distinct zones. It was etched with Gröesbeck reagent, which figures out different types of carbides.

The first thing to point out is the presence of the MC carbide, similar in size to the grains that surround it in the MPZ, which was not affected by melting. Its large size, together with its high melting temperature [4], justify its presence.

The incipient melting of the matrix occurred around these primary carbides, leading to the formation of eutectic carbide in feathery form (Figure 16) in this zone. The eutectic colonies appe- ar distributed in the parallel bands according to the initial structure of steel. The temperature achieved in this area and the time spent were not sufficient for the diffusion of alloying elements during the treatment.

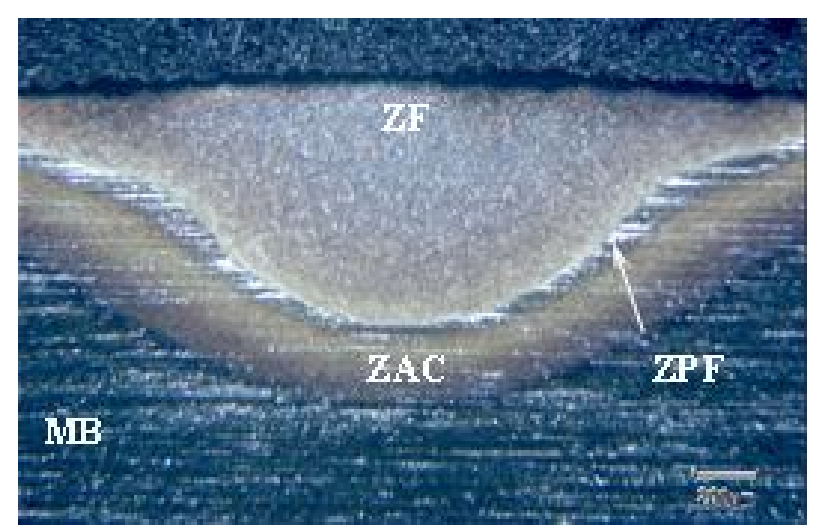

Figure 15. M21 treatment.Vilella reagent.

At the laser melted zone (LMZ) and the partial melted zone (PMZ), the only formed carbide after laser melting was $\mathrm{M}_{2} \mathrm{C}$, with diverse morphology. This is illustrated by the Figure 17, which shows the cross section of the laser melted surface layer. No carbide is observed in the solidified microstructure after etching with alkaline sodium, reagent that reveals the $\mathrm{M}_{6} \mathrm{C}$ carbides but leaves unaffected the $\mathrm{M}_{2} \mathrm{C}$ ones. The high cooling rate from the melting point is responsible for the absence of $\mathrm{M}_{6} \mathrm{C}$ carbide.

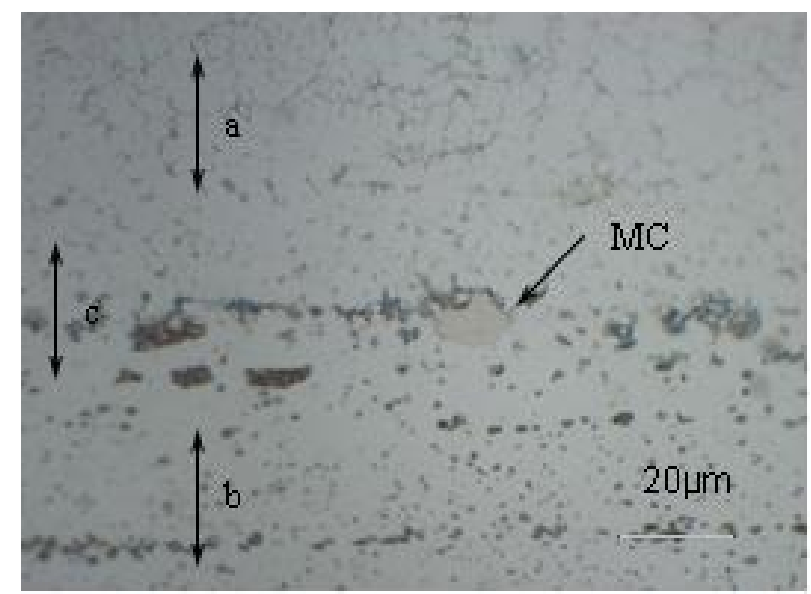

Figure 16. Detail of M21 treatment. Groesbeck reagent. a) $M Z$; b) $H A Z$; c) PMZ. 


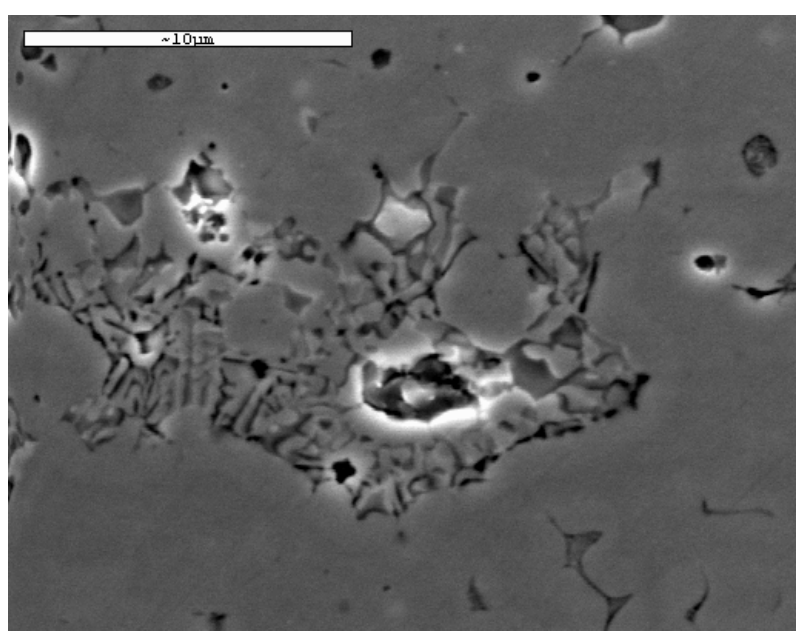

Figure 17. SEM micrographic M21 treatment. Gröesbeck reagent. PMZ zone.

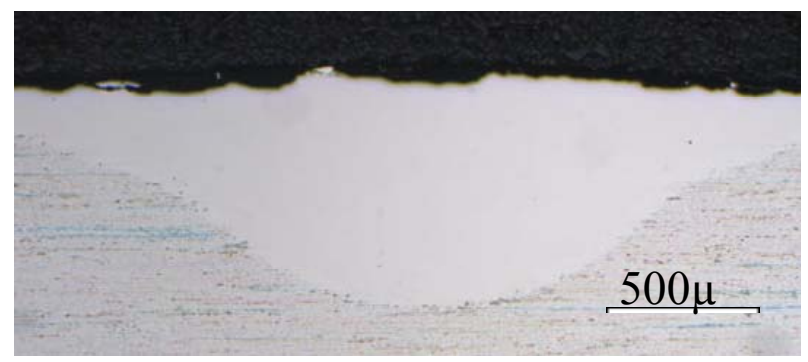

Figure 18. M21 treatment. Alkaline sodium picrate reagent.

The surface layer obtained after the laser surface melting was homogeneous and very refined, with no cracks, discontinuities or porosity.

Figure 18 shows the typical microstructure of the laser melted zone (LSM): fine dendrites (1-2 $\mu \mathrm{m})$ surrounded by a eutectic. The axes of the dendrites seem oriented to the heat transport direction.

Below the laser melting zone, the temperature was between liquidus and solidus temperatures, and a partial melting occurred. This zone, namely the partial melting zone, is not homogeneus. Figure 19 20 shows two different microstructures: The A zones are characterized by the presence of partially large dissolved carbides, MC (about $10 \mu \mathrm{m}$ ), and the B zones which have a cell microstructure. These differences are related to the different quantity of the carbides.

Although the heat flown in the two microstructures of ZPF is the same, the appearance of one or another will depend on the amount of carbides that are in the area where laser melted treatment takes place.

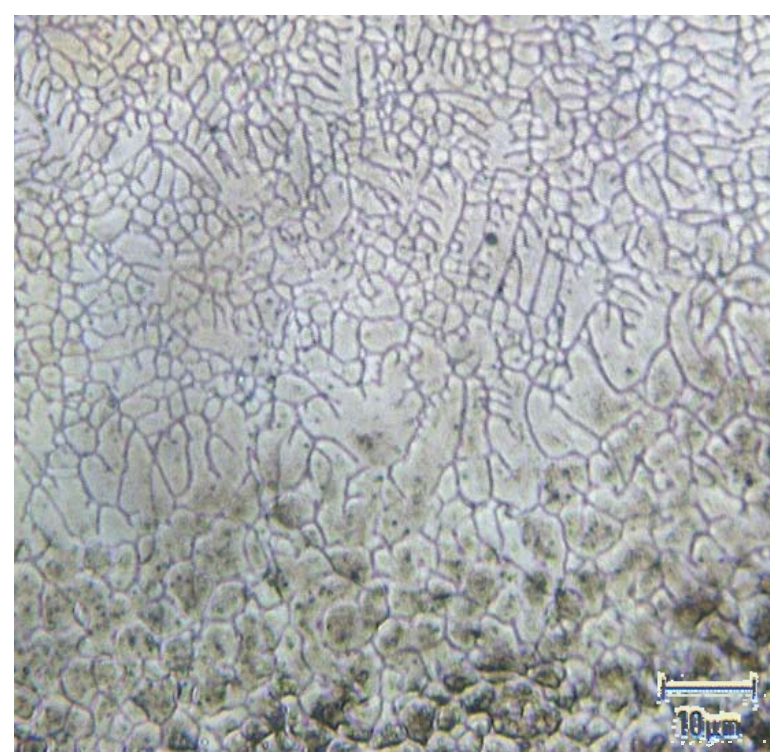

Figure 19. M22 treatment the in MZ. Beraha Reagent.

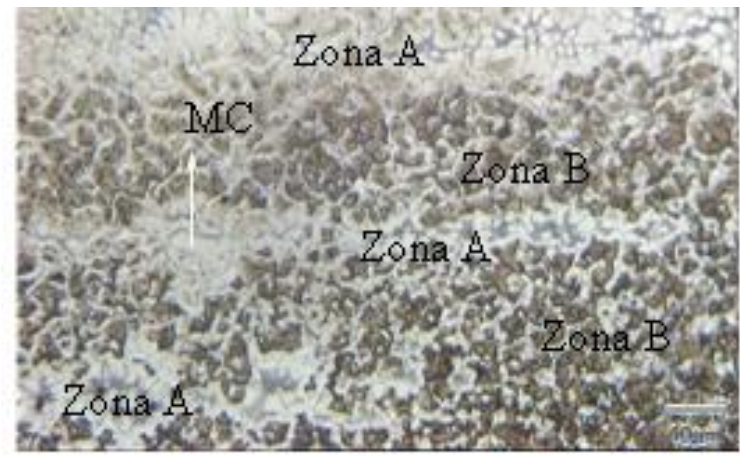

Figure 20. M22 treatment in the MZ. Beraha reagent.

In all cases, a significant increase in surfaced hardness compared to base metal takes place, as shown in the microhardness profiles (Figure 21), carried out on the four treatments, which may be associated with an improvement on wear and fatigue behaviour.

It can be observed the fall of hardness between the HAZ and the base material, due to the low cooling rate in this zone, which generated an overtempered microstructure.

The highest hardness values are recorded in the treatment obtained by high beam scanning speed, which also has the smallest depth. The material has reached a lower temperature because the energy in this treatments was the lowest of all, therefore, austenite shrinks getting a higher amount of martensite during cooling. 


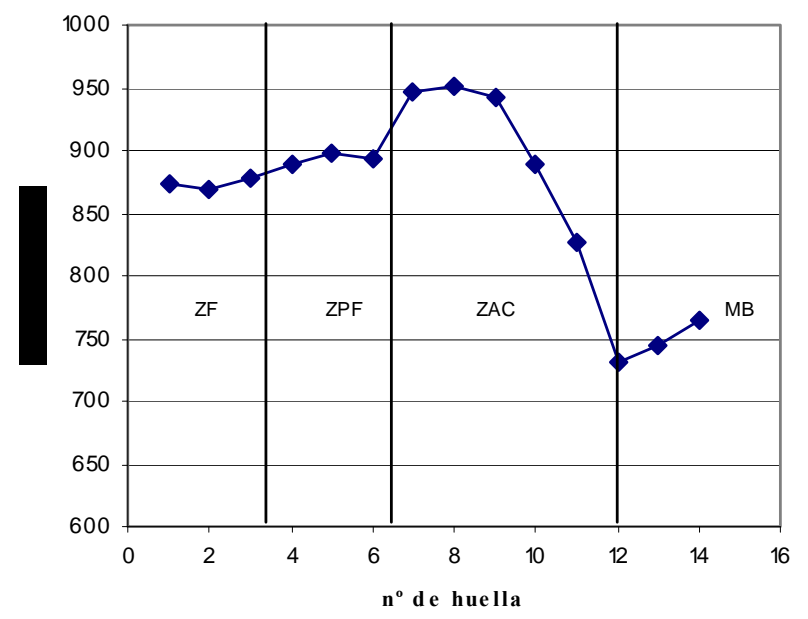

Figure 21. M22 microhardness profile.

Figure 22 shows the wear results. It can be pointed out the existence of decrease in wear coefficient in all cases, compared to the untreated material, and this decline is particularly important in the treatment M2.3.

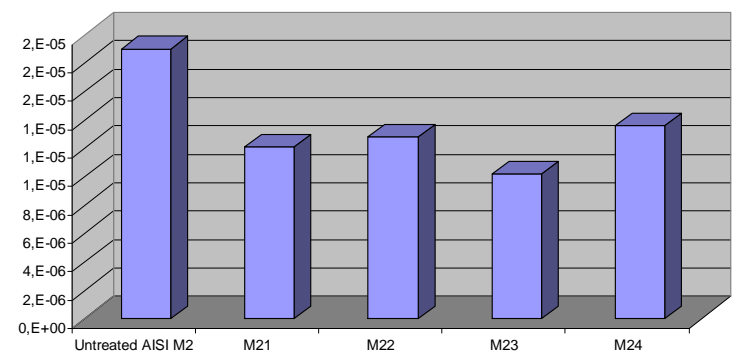

Figure 22. Wear results.

The above presented results of laser melting treatments of M2 tool steel at different laser scanning speed and focal distance can be summarized as follows:

- The cross- sections of the surface layers obtained after different laser melting treatments have four zones: LMZ, PMA, HAZ and BM. They have different microstructure and depth, what is depending on the employed laser parameters.

- $\mathrm{M}_{2} \mathrm{C}$ type is the only re-solidified carbide at the modified layer. Its diverse morphology depends on the solidification cooling speed on the laser melted layer.

- The microstructure of the ZPF is heterogeneous. It has two kinds of microstructures. Their relative quantities do not depend on the laser parameters but on the carbide distribution at the base M2 tool steel.

- Surface hardness increases in all cases, being higher when the lower energy per unit area is provided to steel.

- All treatments have a better wear behaviour than the base material.

\subsection{Laser Cladding}

Figure 23 shows an optical micrograph of the cross section of the Stellite 6 coating. The laser processing conditions were $1500 \mathrm{~W}$ laser power, 8 $\mathrm{mm} / \mathrm{s}$ traverse speed, $9.2 \mathrm{~g} / \mathrm{min}$ powder flow, 10 $1 / \mathrm{min}$ gas protection, and with an overlapping of $55 \%$.

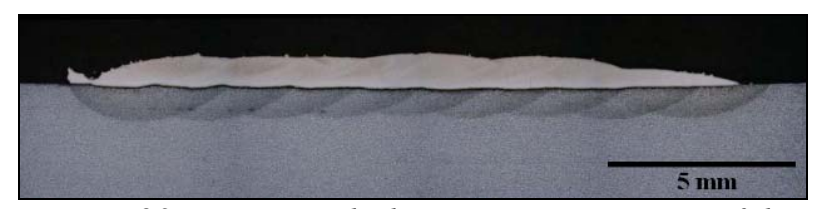

Figure 23. Macrograph showing a cross-section of the Stellite 6 coating.

Figure 24 shows SEM micrographs with the columnar dendritic microstructure of the Stellite 6 . Figure 25 shows a detail of this microstructure. Table 8 shows the EDS analysis performed in different zones of the Figure 24.

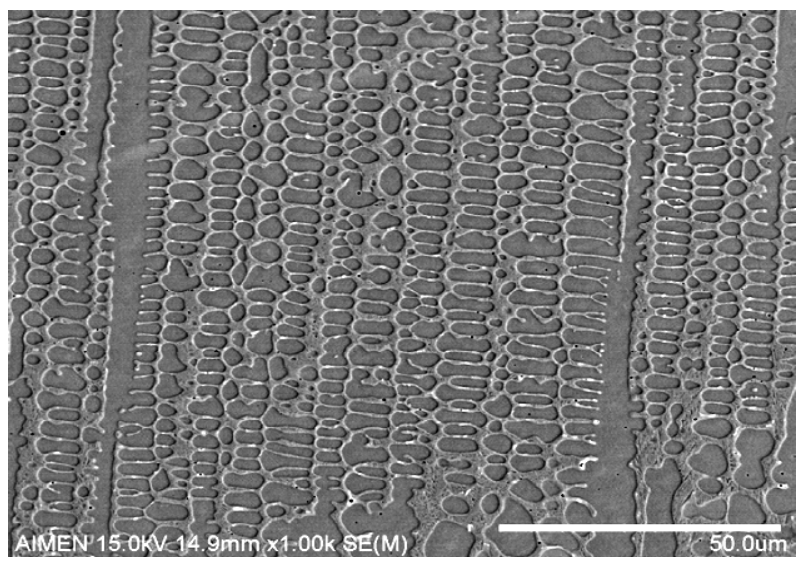

Figure 24. SEM micrographs of the stellite 6 microstructure.

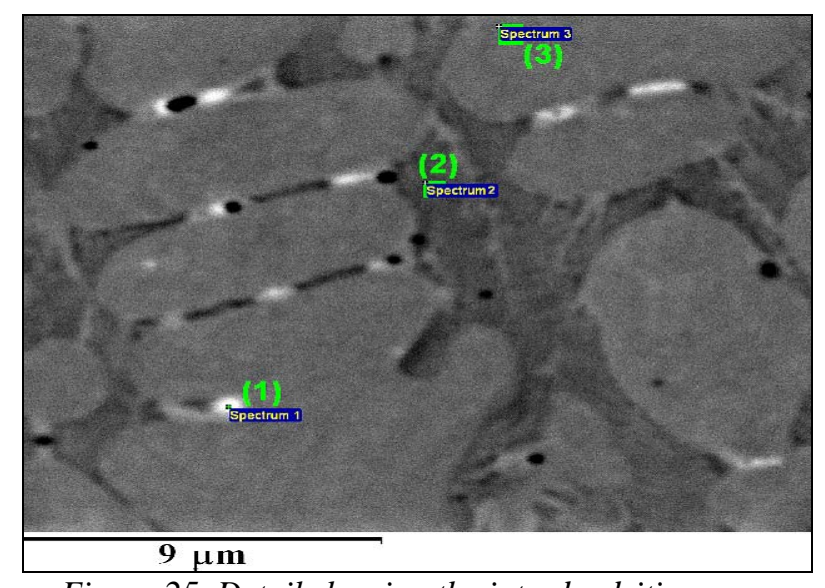

Figure 25. Detail showing the interdendritic space.

Results of Table 8 are coincident with the literature. The microstructure consists of fcc-Co rich solid solution dendrites, surrounded by a lamellar mix- 
ture of the Co-rich phase and carbide phase, resulting from the eutectic reaction whithin inter-dendrite spacing during solidification.

Table 8. EDS analysis of the different phases in 0

\begin{tabular}{|c|c|c|c|c|c|c|c|c|}
\hline Point & $\mathrm{C}$ & $\mathrm{Cr}$ & $\mathrm{Mn}$ & $\mathrm{Fe}$ & $\mathrm{Co}$ & $\mathrm{Ni}$ & $\mathrm{Mo}$ & $\mathrm{W}$ \\
\hline 1 & 6.2 & 22.4 & 0.7 & 5.1 & 37.9 & 1.2 & 3.8 & 20.2 \\
\hline 2 & 8.4 & 37.5 & 0.6 & 5.7 & 36.9 & 1.5 & 0.8 & 7.1 \\
\hline 3 & 6.2 & 24.3 & 0.4 & 8.3 & 52.8 & 2.1 & 0.3 & 4.0 \\
\hline
\end{tabular}

In comparison with the chemical composition of the commercial Stellite 6, it can be seen that dilution of iron in the cladding from the base material is produced. However, this is only produced near the melting line. In the intermediate and upper zones of the Stellite cladding only a little increase of iron was observed.

When producing a Stellite 6 with $0.5 \%$ nano$\mathrm{Y}_{2} \mathrm{O}_{3}$ coating the parameters must be changed, in order to take into account a higher laser absorption by powder compared to Stellite 6 alone. The laser processing conditions were $1100 \mathrm{~W}$ laser power, 10 $\mathrm{mm} / \mathrm{s}$ traverse speed, $8.8 \mathrm{~g} / \mathrm{min}$ powder flow, 10 $1 / \mathrm{min}$ gas protection, and $55 \%$ overlapping of.

Figure 26 shows the microstructure in the upper part of the Stellite 6 with $0.5 \%$ nano- $\mathrm{Y}_{2} \mathrm{O}_{3}$ coating. Figure 27 shows a detail of the dendrites and interdendritic space, showing the typical structure found in the Stellite coating. Table 9 shows the EDS analysis performed in this zone.

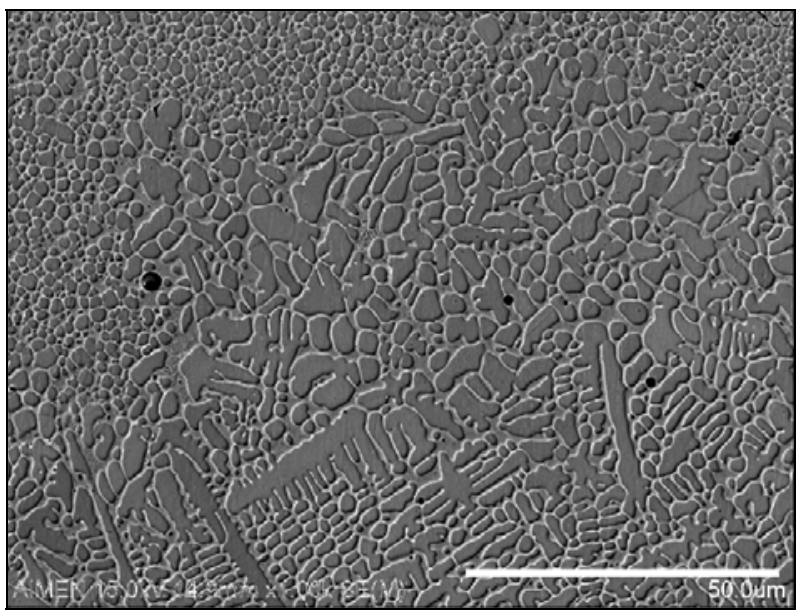

Figure 26. SEM micrographs of the stellite $6+0.5 \%$ Y2O3 microstructure.

It can be seen in Figures 26 and 27 that the solidification microstructure of the coating has changed with the addition of nano- $\mathrm{Y}_{2} \mathrm{O}_{3}$. Without nano$\mathrm{Y}_{2} \mathrm{O}_{3}$ the microstructure appears in thin directional columnar dendrites, perpendicular to the fusion line. With the ceramic nanoparticles, the dendrites significantly change from columnar grain to the equiaxed and cellular microstructure. The dendrites with nano- $\mathrm{Y}_{2} \mathrm{O}_{3}$ become thinner and denser.

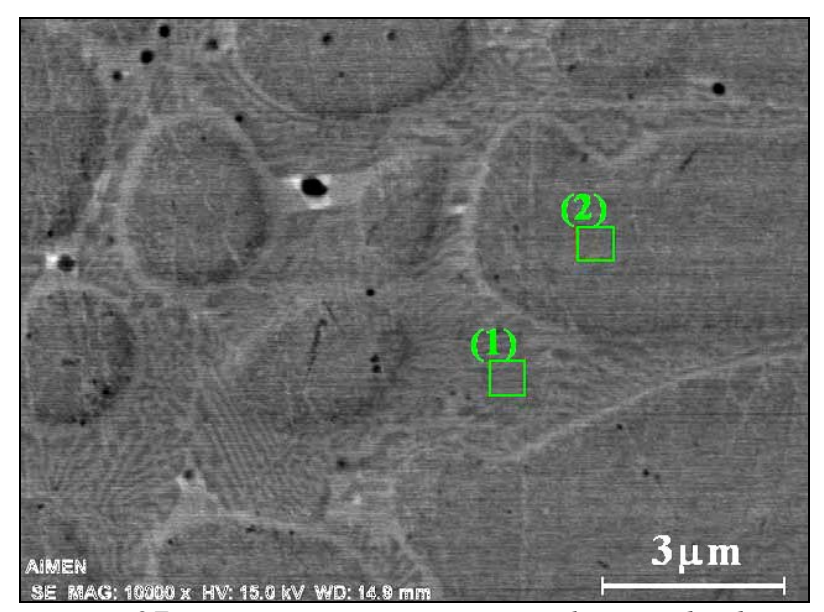

Figure 27. Eutectic microstructure in the interdendritic zone.

Table 9. EDS analysis of the different phases in 0.

\begin{tabular}{|r|c|c|c|c|c|c|c|c|c|}
\hline Pt. & C & Y & Cr & Mn & Fe & Co & Ni & Mo & W \\
\hline 1 & 2.0 & 0.2 & 40.4 & 0.1 & 9.0 & 38.8 & 1.4 & 0.8 & 6.5 \\
\hline 2 & 1.1 & 0.0 & 23.6 & 0.3 & 11.6 & 56.2 & 2.5 & 0.2 & 3.4 \\
\hline
\end{tabular}

Nano- $\mathrm{Y}_{2} \mathrm{O}_{3}$ added to Stellite 6 causes dendrite refinement, promoting heterogeneous nucleation. Moreover, the low thermal conductivity of nano$\mathrm{Y}_{2} \mathrm{O}_{3}$ particles results in lower cooling rate, causing more dilution of the iron from the base metal towards the coating than in Stellite 6 without nanoparticles. However, this dilution is not very high, and the iron content decreases towards the upper zone of the coating.

Due to the high melting point of yttria, this is not dissolved in the melt pool. Therefore, the nanoparticles are segregated to the interdendritic areas, where the eutectic microstructure is formed.

Wear resistance of the stellite 6 coating is not very different of the Stellite 6 with the nano- $\mathrm{Y}_{2} \mathrm{O}_{3}$. The specific wear ratio, $\mathrm{K}$, is $7.84 \times 10^{-5}$ for the first one, and $9.20 \times 10^{-5}$ for the last one. However, the $\mathrm{K}$ for the coating with nanoparticles is slightly higher. The reason could be a different cooling rate between the two coatings. Addition of ceramics to the Stellite 6 modifies the thermal conductivity of the melt pool, promoting that the cooling in the Stellite 6 with nanoparticles is slower.

In comparison of the hardness tests (Table 10) for the Stellite 6 and Stellite 6 with nanoparticles, similar results are obtained. Hardness of the coating with the nano- $\mathrm{Y}_{2} \mathrm{O}_{3}$ is slightly lower than for Stellite 6 as a consequence of the dilution caused by the lower cooling. The more heat supplied to the substrate is reflected in the hardness values of the HAZ. In the 
Stellite 6 coating the HAZ is narrow and the hardness values descend more abruptly.

Table 10. Hardness values across the coating perpendicular to the fusion line for the Stellite 6 and Stellite $6+0.5 \% \mathrm{Y}_{2} \mathrm{O}_{3}$.

\begin{tabular}{|c|c|c|}
\hline Point & Stellite 6 & $\begin{array}{c}\text { Stellite } 6+ \\
0.5 \% \text { nano- } \mathrm{Y}_{2} \mathrm{O}_{3}\end{array}$ \\
\hline 1 & 537 Coating & 494 Coating \\
\hline 2 & 564 Coating & 513 Coating \\
\hline 3 & 553 Coating & 502 Coating \\
\hline 4 & 524 Coating & 487 Coating \\
\hline 5 & 408 melting line & 505 Coating \\
\hline 6 & $135 \mathrm{HAZ}$ & $189 \mathrm{HAZ}$ \\
\hline 7 & $136 \mathrm{HAZ}$ & $174 \mathrm{HAZ}$ \\
\hline 8 & $137 \mathrm{HAZ}$ & $130 \mathrm{BM}$ \\
\hline 9 & $121 \mathrm{BM}$ & $135 \mathrm{BM}$ \\
\hline 10 & $125 \mathrm{BM}$ & $136 \mathrm{BM}$ \\
\hline 11 & $129 \mathrm{BM}$ & \\
\hline
\end{tabular}

The following conclusions can be drawn from this study on Stellite 6 nano- $\mathrm{Y}_{2} \mathrm{O}_{3}$ coating by laser cladding:

- Laser cladding is an effective method to produce microstructure refinement in a Co alloy coating when $\mathrm{Y}_{2} \mathrm{O}_{3}$ nanoparticles are added.

- Nano- $\mathrm{Y}_{2} \mathrm{O}_{3}$ added to Stellite 6 causes dendrite refinement promoting heterogeneous nucleation. Microstructure significantly changes from the columnar grain to an equiaxed and cellular microstructure. The dendrites with nano- $\mathrm{Y}_{2} \mathrm{O}_{3}$ become thinner and denser.

- Since yttria is not dissolved in the melt pool, nanoparticles are segregated to the interdendritic areas, where the eutectic microstructure is formed.

- Low thermal conductivity of nano- $\mathrm{Y}_{2} \mathrm{O}_{3}$ particles results in the lower cooling rate causing more dilution of iron from the base metal towards the coating than in Stellite 6 without nanoparticles. This cause a slightly lower hardness in Stellite+ nano- $\mathrm{Y}_{2} \mathrm{O}_{3}$

\section{CONCLUSIONS}

It has been shown the ability of laser technology to improve the surface wear behaviour and local mechanical resistance of different steels used in industry by means of several processes: hardening, melting and cladding.

\section{ACKNOWLEDGEMENTS}

Authors wish to thank Xunta de Galicia and Spanish Ministerio de Ciencia e Innovación for their financial support, especially through projects PGIDT05TMT00405CT, PGIDIT-06TMT00402CT, and IAP-600200-2008-52.

\section{REFERENCES}

[1] http://www.worldautosteel.org/

[2] D. Schuocker, Handbook of the Eurolaser Academy, Ed. Chapman-Hall, 1998.

[3] W. M. Steen, "Laser Material processing", Springer, 2003.

[4] M. Heitkemper, Al Fischer, Ch. Bohne, A. Pyzalla, Wear mechanisms of laser-hardened martensitic high-nitrogen-steels under sliding wear, Wear 250 (2001) 477-487.

[5] T.R. Jervis, M. Nastasi, A.J. Griffin, Jr., T.G. Zocco, T. N. Taylor, S. R. Foltyn, Tribological effects of excimer laser processing of tool steel, Surface and Coatings Technology 89 (1997) 158-164.

[6] G. Duffet, P. Sallamand, A. B. Vannes, Improvement in friction by $\mathrm{cw}$ Nd:YAG laser surface treatment on cast iron cylinder bore, Applied Surface Science 205 (2003) 289-296.

[7] M. Bonek, L.A. Dobrzanski, E. Hajduczek, A. Klimpel, Structure and properties of laser alloyed surface layers on the hot-work tool steel, Journal of Materials Processing Technology 175 (2006) 45-54.

[8] L. A. Dobrzanski M. Bonek, , E. Hajduczek, A. Klimpel, Alloying the X40CrMoV5-1 steel surface layer with tungsten carbide by the use of a high power diode laser, Applied Surface Science 247 (2005) 328-332.

[9] L. A. Dobrzanski, M. Bonek, E. Hajduczek, A. Klimpel, A Lisiecki, Comparison of the structures of the hot-work tool steels laser modified surface layers, Journal of Materials Processing Techonolgy 164-165 (2005) 1014-1024.

[10] D. I. Pantelis, E. Bouyouri, N. Kouloumbi, P.Vassiliou, A.Koutsomichalis, Wear and corrosion resistance of laser surface hardened structural steel, Surface and Coatings Technology 298 (2002)125-134.

[11] K. H. Lo, F. T. Cheng, C. T. Kwok, H. C. Man, Effects of laser treatments on cavitation erosion and corrosion of AISI 440C martensitic Stainless steel, Material Letters 58 (2003) 88-93.

[12] S Kaç, J. Kusinski, SEM and TEM microstructural investigation of high-speed tool steel after 
laser melting, Materials Chemistry and Physics. 81 (2003 510-512.

[13] W. Darmawan, J. Quesada, R. Marchal, Characteristics of laser melted AISI T1 high speed steel and its wear resistance, Surface Engineering 23 (2007) 112-119.

[14] H. Fredriksoon, S. Brising, Formation of carbides during solidification of high speed steels, Scand J Metal. 5 (1976) 268-275.

[15] C. T. Kwok, F. T. Cheng, H. C Man, Microstructure and corrosion behavior of laser surface-melted high-speed steels, Surface and Coating Technology 202 (2007) 336-348.

[16] M. Li, Y. He, X. Yuan, Sh. Zhang, Microstructure of $\mathrm{Al}_{2} \mathrm{O}_{3}$ nanocrystalline/cobalt-based alloy composite coatings by laser deposition, Materials and Design 27 (2006) 1114-1119

[17] M. Li, Sh. Zhanga, H. Li, Y. Hea, J.-H. Yoonb, T.-Y. Cho, Effect of nano- $\mathrm{CeO}_{2}$ on cobaltbased alloy laser coatings, Journal of materials processing technology 202 (2008) 107-111

[18] Sh. H. Zhang, M. X. Li, T. Y. Cho, J. H. Yoon, Ch. G. Lee, Y. Z. He, Laser clad Ni-base alloy added nano- and micron-size $\mathrm{CeO}_{2}$ composites, Optics \& Laser Technology 40 (2008) 716-722.

[19] E. Rabinowicz, Friction and Wear of materials, John Wiley and Sons, 1995.

$\operatorname{son} 8$

\section{ОБРАДА ПОВРШИНА ЛАСЕРСКОМ ТЕХНОЛОГИЈОМ}

Сажетак: За индустријске примјене потребни су дијелови компоненти са специфичним особинама површина као што су добра отпорност на корозију, отпорност на хабање и чврстоћа. Легуре које имају та својства обично су веома скупе, те постоји велики интерес за смањењем цијене компоненти како би се испунили ови захтјеви. У овом погледу, ласерска обрада површина користи се као економична техника за побољшање својстава површина материјала, коришћењем топлоте ласерског зрака за модификовање њене структуре и физичких карактеристика. Ласерска обрада површина може се подијелити у директне процесе, за које је потребно само генерисати топлоту, као што је каљење и поновно топљење, и процесе за које је потребан материјал за испуну као што је легирање и облагање. Стога је циљ овог рада да се сумирају резултати неколико истраживања заснованих на ласерској обради површина. Нарочито, каљење и поновно топљење хладно ваљаних челика, облагање при изради алата и ласерско легирање наночестицама.

Микроструктурна карактеризација и механичка својства (микрочврстоћа, отпорност на хабање) биће описани у сваком појединачном случају. Биће анализирана побољшања отпорности на корозију.

Кључне ријечи: ласер, облагање, каљење, наночестице, Nd:YAG, диодни лаcep. 